\title{
Quantitative study of endocrine cells immunoreactive for calcitonin in the normal adult human lung
}

\author{
JOHN R GOSNEY, MCJ SISSONS, JA O'MALLEY \\ From the Department of Pathology, University of Liverpool
}

\begin{abstract}
There was no significant variation in the numbers of bronchopulmonary endocrine cells immunoreactive for calcitonin in five pairs of adult human lungs either from case to case or between groups of anatomically equivalent lobes. This was the case whether their numbers were expressed in relation to epithelial length or to the total number of epithelial cells. The mean (SD) values for the frequency of occurrence of these cells in all 25 lobes studied were 4.3 (1.9) per 10 $\mathrm{cm}$ of epithelial length or $1.70(0.78)$ per 10000 epithelial cells. Most immunoreactive cells were single and situated in the airways; only three neuroepithelial bodies were observed, and no cells were present in the parenchyma examined. This study provides further evidence that the functional character of these cells may not be confined to early life.
\end{abstract}

Recent studies have revealed the presence of several peptides in the bronchopulmonary endocrine cells of the human lung. These include calcitonin, leucine enkephalin, and gastrin releasing peptide..$^{1-3}$ Little is known of the frequency of such cells within the total epithelial population of the airways or the alveoli. Such information has become particularly important in view of recent studies showing apparent hyperplasia of these endocrine cells in ectatic bronchi and in lungs containing "carcinoid" neoplasms and carcinomas. ${ }^{4}$ This study was performed to determine accurately the frequency of occurrence of those endocrine cells immunoreactive for calcitonin in normal adult human lungs, and to compare their frequency in different lobes and different subjects.

\section{Methods}

Five suitable cases were chosen from those coming to necropsy in the university department of pathology at the Royal Liverpool Hospital. The age and cause of death are shown for each of these in table 1 . Particular care was taken to ensure that none had any history during life or evidence at necropsy of respiratory disease, pathological conditions of the thyroid or parathyroid glands, or disordered calcium metabolism-factors that may, in theory, affect

Address for reprint requests: Dr JR Gosney, University Department of Pathology, Royal Liverpool Hospital, Liverpool L7 8XP.

Accepted 21 May 1985 those pulmonary endocrine cells that contain calcitonin. The interval between death and the performance of the necropsy was also important. In no case was this greater than 18 hours. Permission for the study had been obtained from the hospital ethical committee.

The lungs were removed intact and gently distended by perfusion with Bouin's solution via a wide rubber tube inserted into the proximal trachea. Once a state of firm but not tight distension had been reached, the tubing was removed, the trachea ligated, and the whole specimen immersed in a large container of Bouin's solution, where it was allowed to fix for 24 hours. Blocks of tissue were taken at intervals of about $2 \mathrm{~cm}$ along the airways starting in the mid tracheal region. This allowed sampling of airways from all lobes, and also provided for study of a considerable amount of parenchyma. Although anatomical variation from subject to subject renders precise reproduction of the sites of sampling impossible, close approximation between cases is achievable with care. By this means a total of about 45 tissue blocks was obtained from each lung.

The blocks of tissue were embedded in paraffin

Table 1 Age, sex, and cause of death of subjects studied

\begin{tabular}{llll}
\hline Subject No & Age $(y)$ & Sex & Cause of death \\
\hline 1 & 76 & F & Cerebral haemorrhage \\
2 & 82 & F & Myocardial infarction \\
3 & 72 & M & Cerebral haemorrhage \\
4 & 58 & F & Myocardial infarction \\
5 & 70 & M & Subarachnoid haemorrhage \\
\hline
\end{tabular}


wax and serial sections of $4 \mu \mathrm{m}$ thickness were cut from each. These were stained with haematoxylin and eosin and labelled for calcitonin by the peroxidase antiperoxidase (PAP) method. ${ }^{5}$ A polyclonal antiserum raised to human calcitonin in rabbit and purchased from the Dako Corporation of Denmark was used. A working dilution of 1:8000 provided optimum contrast between positive staining and non-specific background coloration. Incubation was for 18 hours at $4^{\circ} \mathrm{C}$ under conditions of constant humidity. Liquid phase absorption studies were performed in which increasing amounts of purified calcitonin, katacalcin, calcitonin gene related peptide (CGRP), gastrin releasing peptide (GRP), leucine enkephalin, and adrenocorticotrophic hormone (ACTH) were added to $1 \mathrm{ml}$ aliquots of antiserum at working dilution and incubated for 18 hours at $4^{\circ} \mathrm{C}$. Addition of $0.1 \%$ bovine serum albumin prevented non-specific absorption. After subsequent staining of selected tissues, the addition of only calcitonin at a concentration of $25 \mathrm{ng}$ per $\mathrm{ml}$ of antiserum quenched positivity. None of the other antigens had any effect at concentrations of up to $100 \mu \mathrm{g}$ per ml. The anticalcitonin serum was linked to rabbit immunoglobulin peroxidase complex diluted to 1:200, by swine antirabbit immunoglobulin serum at a dilution of 1:20. The latter acted as a "bridge." After the addition of hydrogen peroxide, the reaction product was demonstrated by using the chromogen 3-amino-9-ethylcarbazole (AEC). All solutions were diluted in phosphate buffered saline (PBS) at $\mathrm{pH}$ 7.2. Prior incubation of the sections for 30 minutes in a solution of $1 \%$ hydrogen peroxide in methanol, and for 20 minutes in non-immune swine serum, prevented false positive staining due to endogenous peroxidase and non-specific binding of immunoglobulin respectively. With each batch of sections, thorough positive and negative control procedures were performed. The former consisted of the labelling of sections of tissue from several cases of human medullary carcinoma of the thyroid and of sections of human and non-human thyroid glands. The latter consisted of omission of each stage of the procedure outlined above, the replacement of the primary antiserum with antisera to peptides other than calcitonin, and the replacement of the swine antirabbit immunoglobulin serum with antisera to immunoglobulins from other species. Labelled sections were mounted in glycerol.

After subjective study of immunoreactive cells, their distribution was studied and their number quantified for each lobe of each lung. Several different methods have been used in the past in attempts to quantify bronchopulmonary endocrine cells. ${ }^{6-10}$ The method used in the present study is very similar to that of Kleinerman et $a l^{10}$ in that the number of cells immunoreactive for calcitonin has been expressed per 10000 epithelial cells as well as.per 10 $\mathrm{cm}$ of airway epithelium. The former allows for variation in the total number of epithelial cells in a given length of mucosa. Sections were therefore first examined with a Leitz Wetzlar Dialux microscope fitted with a linear eyepiece graticule. All the airways and parenchyma contained in each section were studied. At a magnification of $\times 400$ the total number of epithelial cells contained between the extremities of the linear graticule were counted, wherever possible, at three sites for each airway. After calibration with a stage micrometer, the total number of epithelial cells per unit length of epithelium was calculated. The number and position of endocrine cells immunoreactive for calcitonin in airways and parenchyma were noted. By means of a Zeiss projecting microscope each section was projected on to a large sheet of paper and a tracing made to outline all airways, vessels, and parenchyma. The precise magnification was determined for each tracing by projecting on to the paper the image of the stage micrometer. The length of the perimeter of each airway and the area occupied by alveoli were measured by planimetry. The position of all immunoreactive cells was transferred to the tracing. From the data thus obtained the number of immunoreactive cells per $10 \mathrm{~cm}$ length of epithelium, the number per 10000 epithelial cells, and the number per square centimetre of parenchyma were calculated.

Study of sections adjacent to these, stained with haematoxylin and eosin, served to exclude any undiscovered pathological changes.

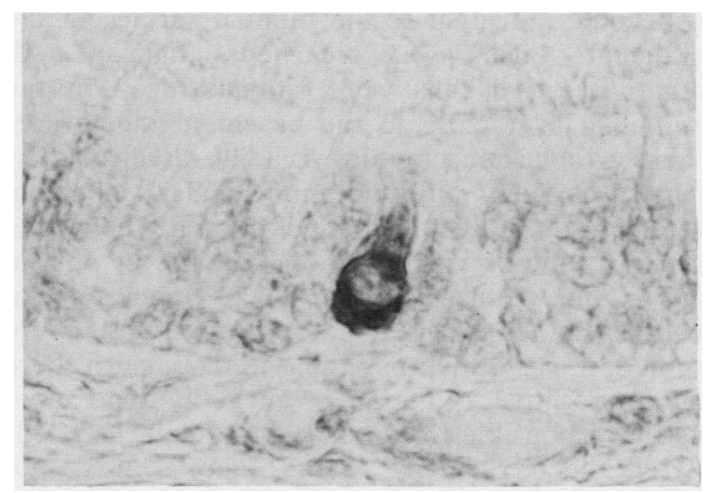

A single endocrine cell immunoreactive for calcitonin in a human bronchus. The basal concentration of its granular content is notable but its cytoplasm extends towards the luminal border of the epithelium. (Peroxidase antiperoxidase method for calcitonin, $\times 1200$.) 
Table 2 Number of cells immunoreactive for calcitonin in the lungs of five normal human subjects

\begin{tabular}{|c|c|c|c|c|c|c|c|}
\hline Lobe & & 1 & 2 & 3 & 4 & 5 & $\begin{array}{l}\text { Mean for each group of } \\
\text { equivalent lobes }\end{array}$ \\
\hline \multirow[t]{2}{*}{ Right upper } & L & 2.4 & 3.0 & 3.1 & 8.0 & 3.2 & 3.94 \\
\hline & $\mathbf{N}$ & 0.90 & 1.11 & 1.16 & 3.18 & 1.27 & 1.52 \\
\hline \multirow{2}{*}{ Right middle } & $\mathrm{L}$ & 4.1 & 3.6 & 5.9 & 4.4 & 7.2 & 5.04 \\
\hline & $\bar{N}$ & 1.58 & 1.56 & 2.28 & 1.62 & 2.83 & 1.97 \\
\hline \multirow{2}{*}{ Right lower } & L & 9.0 & 7.8 & 3.1 & 2.7 & 2.5 & 5.02 \\
\hline & $\mathbf{N}$ & 3.68 & 3.2 & 1.19 & 1.02 & 0.93 & 2.0 \\
\hline \multirow[t]{2}{*}{ Left upper } & L & 3.3 & 2.8 & 3.5 & 4.2 & 2.5 & 3.26 \\
\hline & $\overline{\mathbf{N}}$ & 1.30 & 1.09 & 1.56 & 1.65 & 0.94 & 1.31 \\
\hline \multirow[t]{2}{*}{ Left lower } & L & 3.5 & 3.6 & 5.8 & 4.4 & 3.4 & 4.14 \\
\hline & $\mathbf{N}$ & 1.44 & 1.48 & 2.24 & 1.75 & 1.44 & 1.67 \\
\hline \multirow{2}{*}{$\begin{array}{l}\text { Mean for each } \\
\text { subject }\end{array}$} & L & 4.46 & 4.16 & 4.28 & 4.74 & 3.76 & $4.3^{*}$ \\
\hline & $\mathbf{N}$ & 1.78 & 1.69 & 1.69 & 1.84 & 1.48 & $1.70^{*}$ \\
\hline
\end{tabular}

*Mean values for both lungs of all subjects.

$\mathrm{L}-$ Number of immunoreactive cells per $10 \mathrm{~cm}$ of epithelial length; $\mathrm{N}$-number per 10000 epithelial cells.

\section{Results}

Some details of the subjects studied are shown in table 1 . They ranged in age from 58 to 82 years; two were male and three female. All died of an acute illness.

Subjective examination of sections labelled for calcitonin showed immunoreactive cells to occur infrequently at all levels of the respiratory tract apart from the alveoli, where none were identified in a total alveolar area of $416 \mathrm{~cm}^{2}$. The vast majority were single cells, and very few comprised the innervated clusters of endocrine cells that Lauweryns has termed neuroepithelial bodies. ${ }^{112}$ Such neuroepithelial bodies immunoreactive for calcitonin were found on only three occasions, one each in subjects 2,4 , and 5 . The single cells were typically of columnar morphology. In many cases long, tenuous, cytoplasmic processes extended towards the lumen of the airway, passing between adjacent epithelial cells to become indistinct as the luminal surface of the epithelial layer was reached (figure). All immunoreactive cells were situated deep in the epithelial layer close to the basement membrane. Their cytoplasmic granules, readily discernible by light microscopy after immunochemical labelling, were concentrated at the base of the cell. They were, however, always visible throughout the cytoplasm and in the cytoplasmic extensions. When adjacent sections stained with haematoxylin and eosin were studied, it was quite impossible to distinguish these immunoreactive cells. Their allegedly pale cytoplasm, responsible for their being named clear cells ("Hellezellen") many years ago, ${ }^{13}$ was not sufficiently distinctive to permit their identification without the benefit of prior knowledge of their location.

Table 2 shows the values for the number of immunoreactive cells expressed per $10 \mathrm{~cm}$ of epithelium and per 10000 epithelial cells. As might be expected from the similarity of the figures for the total number of epithelial cells per $\mathrm{mm}$ of epithelium, the values obtained by these two methods of expression correlated very closely. For the 25 lobes studied, the number of immunoreactive cells expressed per $10 \mathrm{~cm}$ of epithelial length ranged from 2.4 to 9.0 , with a mean and standard deviation of 4.3 (1.9). When expressed per 10000 epithelial cells, the number of immunoreactive cells ranged from 0.90 to 3.68 , with a mean (SD) of $1.70(0.78)$. Analysis of variance by application of the $F$ test showed no significant variation from subject to subject or between groups of equivalent lobes. Neither was there any significant variation between left and right lungs.

\section{Discussion}

The lung has only recently come to be widely recognised as having an endocrine function in addition to its role in the transfer of gases between the environment and the bloodstream, although the presence of endocrine cells in the airways was proposed almost 50 years ago. ${ }^{14}$ is The presence of calcitonin was demonstrated in the endocrine cells of the lungs of six human neonates in 1980 , and this was soon followed by the demonstration of leucine enkephalin and gastrin releasing peptide, the mammalian analogue of bombesin. ${ }^{3}$ Little is known about the pattern of distribution of these subpopulations in either normal or diseased lungs. Some previous studies have addressed themselves to the investigation of this problem; but they have relied on methods that do not permit distinction of the cell types according to their content of peptide, and they have not furnished quantitative data. ${ }^{16}{ }^{17}$ The major obstacle to such quantitative study is the scarcity of these cells. Sampling of tissue must be widespread to 
ensure a representative result. In the case of the 10 lungs examined in the present study, 10-20 blocks of tissue were taken from each lobe. Although this was sufficient to provide a fully representative figure for the lobe as a whole, it was still not enough to permit variation in the frequency of cells between different classes of airway to be determined.

The number of endocrine cells immunoreactive for calcitonin in the lungs of these five subjects showed remarkably little variation either from case to case or between groups of equivalent lobes. There is nothing, for example, to suggest that these cells are more prevalent in those parts of the lungs which are relatively poorly perfused (the apices) or relatively poorly ventilated (the bases). It is also notable that the subjects studied were relatively elderly, with a mean age of 73.6 years; and although these cells were infrequent they were readily demonstrable in all cases. This is further evidence to support the contention that their role is not confined merely to the fetal and early neonatal period. ${ }^{6}$ Unfortunately, we are still quite ignorant of their function and their purpose is a matter of conjecture at present.

The two methods of expressing the frequency of calcitonin containing endocrine cells provide data that agree very closely. The importance of expressing the number of immunoreactive cells in terms of the total epithelial cell population becomes obvious given that stimuli affecting the number of endocrine cells may also alter the size of the total epithelial population. For example, it has recently been shown that when rats are treated with diethylnitrosamine, a potent carcinogen, there is an increase not only in the size of the population of endocrine cells in the bronchi, as identified by silver impregnation, but also in the total number of epithelial cells. ${ }^{10} \mathrm{~A}$ real change in the size of a population of endocrine cells could conceivably remain undetected if a generalised alteration in the number of epithelial cells had also occurred. Such careful analysis needs to be applied to the study of diseased lungs, in which subjective assessment of endocrine cells has already shown an apparent hyperplasia in the presence of ectatic bronchi and primary bronchial neoplasms. ${ }^{4}$

We would like to thank Mr AR Williams for photographic assistance, and Miss C Youd for typing the manuscript. This work was part of a larger study supported by the Mersey Regional Health Authority.

\section{References}

1 Becker KL, Monaghan KG, Silva OL. Immunocytochemical localization of calcitonin in Kulchitsky cells of human lung. Arch Pathol Lab Med 1980; 104: 196-8.

2 Cutz E, Chan W, Track NS. Bombesin, calcitonin, and leu-enkephalin immunoreactivity in endocrine cells of human lung. Experientia 1981;37:765-7.

3 Tsutsumi Y, Osamura RY, Watanabe K, Yanaihara N. Immunohistochemical studies on gastrin-releasing peptide and adrenocorticotropic hormone-containing cells in the human lung. Lab Invest 1983;48:623-32.

4 Memoli VA, Linnoila I, Warren WH, Rios-Dalenz J, Gould VE. Hyperplasia of pulmonary neuroendocrine cells and neuroepithelial bodies. Lab Invest 1983;48:57A (abstract).

5 Sternberger LA. The unlabelled antibody peroxidaseantiperoxidase (PAP) method. In: Sternberger LA. Immunocytochemistry. New York: John Wiley 1979:104-69.

6 Moosavi H, Smith P, Heath D. The Feyrter cell in hypoxia. Thorax 1973;28:729-41.

7 Taylor W. Pulmonary argyrophil cells at high altitude. $J$ Pathol 1977;122:137-44.

8 Hernandez-Vasquez A, Will JA, Quay WB. Quantitative characteristics of the Feyrter (APUD) cells of the neonatal rabbit lung in normoxia and chronic hypoxia. Thorax 1977;32:449-56.

9 Palisano JR, Kleinerman J. APUD cells and neuroepithelial bodies in hamster lung: methods, quantitation, and response to injury. Thorax 1980; 35:363-70.

10 Kleinerman J, Marchevsky AM, Thornton J. Quantitative studies of APUD cells in airways of rats. Am Rev Respir Dis 1981;124:458-62.

11 Lauweryns JM, Cokelaere M, Theunynck P. Neuroepithelial bodies in the respiratory mucosa of various mammals: a light optical, histochemical, and ultrastructural investigation. $Z$ Zellforsch Mikrosk Anat 1972;135:569-92.

12 Lauweryns JM, Peuskens J. Neuro-epithelial bodies (neuroreceptor or secretory organ?) in human infant bronchial and bronchiolar epithelium. Anat Rec 1972;172:471-81.

13 Frohlich F. Die "Helle Zelle" der Bronchialschleimhaut und ihre Beziehungen zum Problem der Chemoreceptoren. Frankfurter Z Pathol 1949; 60:517-59.

14 Feyrter F. Über diffuse endokrine epitheliale Organe. Leipzig: JA Barth, 1938.

15 Gould VE. The endocrine lung. Lab Invest 1983; 48:507-9.

16 Tateishi R. Distribution of argyrophil cells in adult human lungs. Arch Pathol 1973;96:198-202.

17 Hage E, Hage J, Juel G. Endocrine-like cells of the pulmonary epithelium of the human adult lung. Cell Tiss Res 1977;178:39-48. 